\title{
ИЗУЧЕНИЕ БИОЛОГИЧЕСКОГО ДЕИСТВИЯ ОТДЕЛЬНЫХ ФРАКЦИЙ ПОЛИФУНКЦИОНАЛЬНЫХ КИСЛОТ НА РАЗВИТИЕ ОВОЩНЫХ И БОБОВЫХ КУЛЬТУР
}

Известно, что сланцевые полифункциональные кислоты (ПФК) основа для синтеза сланцевого ростового вещества (СРВ) - представляют собой естественную смесь кислот, получающуюся в процессе окисления керогена кукерсита азотной кислотой и воздухом и различающихся между собой по величине молекул, а также по количеству и характеру функциональных групп в молекуле [']. С помощью растворителей ПФК довольно четко разделяются на фракции - водорастворимую, эфирорастворимую и нерастворимую в эфире.

В предыдущем сообщении приведены результаты действия суммарного продукта на отдельные органы растений табака (сорт 'Трапезонд 1867 ' и гибрид 'Иммунного' с 'Маловатой'). Целью настоящего опыта было выявить фракции ПФК, обладающие сравнительно большей активностью. Для этого суммарные ПФК были разделены на водорастворимую и водонерастворимую фракции.

Из каждой фракции ПФК были приготовлены калиевые соли, которые и опробовались в качестве биологически активных веществ, влияющих на рост, развитие и урожай томатов, гогошар и фасоли.

\section{1. Действие калиевых солей отдельных фракций ПФК на урожай томатов и гогошар}

В качестве опытного материала использовалась рассада томатов (сорт 'Молдавский ранний 83') и гогошар, корневая система которых перед высадкой в грунт замачивалась в течение 5 ч в $0,01 \%$ и $0,025 \%$-ных растворах СРВ.

Для стимулирования использовались водные растворы калиевых солей ПФК и фракций - водорастворимой и водонерастворимой. Корневая система контрольных растений замачивалась в воде.

Посадка произведена 29 мая 1969 г. Через две недели после посадки опытные растения обрабатывались по методике, . использованной Н. Якушкиной и Л. Чуйковой $\left[{ }^{2,3}\right]$. Растения опрыскивались дважды с недельным интервалом растворами стимуляторов возрастающих концентраций: 0,01 и $0,025 \%$ (по 50 мл на куст для гогошар и по 100 м для томатов).

Наблюдения за развитием растений проводились в течение всего вегетационного периода. Опытные растения внешне развивались лучше контрольных, были намного крупнее и расцвели раньше на 7-10 дней. Между растениями, об́работанными растворами солей отдельных фракций ПФК, видимой разницы не наблюдалось. 
Эффективность действия растворов калиевых солей ПФК

и отдельных фракций на урожай томатов и гогошар

\begin{tabular}{|c|c|c|c|c|c|c|c|c|c|c|c|c|c|}
\hline \multirow{3}{*}{ Наименование проб } & \multirow{3}{*}{ 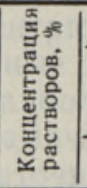 } & \multicolumn{6}{|c|}{ Томаты } & \multicolumn{6}{|c|}{ Гогошары } \\
\hline & & \multicolumn{2}{|c|}{$\begin{array}{c}\text { Bec } \\
\text { одного } \\
\text { плода } \\
\end{array}$} & \multicolumn{2}{|c|}{$\begin{array}{l}\text { Количество } \\
\text { плодов } \\
\text { на куст } \\
\end{array}$} & \multicolumn{2}{|c|}{$\begin{array}{l}\text { У рожай } \\
\text { с одного } \\
\text { куста }\end{array}$} & \multicolumn{2}{|c|}{$\begin{array}{c}\text { Bec } \\
\text { одного } \\
\text { плода }\end{array}$} & \multicolumn{2}{|c|}{\begin{tabular}{|c|} 
Количество \\
плодов \\
на куст \\
\end{tabular}} & \multicolumn{2}{|c|}{$\begin{array}{l}\text { Урожай } \\
\text { с одного } \\
\text { куста }\end{array}$} \\
\hline & & e & $\%$ & штук & $\%$ & 2 & $\%$ & 2 & $\%$ & штук & $\%$ & 2 & $\%$ \\
\hline $\begin{array}{l}\text { Суммарная проба } \\
\text { ПФК }\end{array}$ & $\begin{array}{l}0,01 \\
0,025\end{array}$ & $\begin{array}{l}64,5 \\
67,5\end{array}$ & $\begin{array}{l}104 \\
109\end{array}$ & $\begin{array}{l}32,3 \\
34,7\end{array}$ & $\begin{array}{l}108 \\
116\end{array}$ & $\begin{array}{l}2099 \\
2347\end{array}$ & $\begin{array}{l}113 \\
127\end{array}$ & $\begin{array}{l}46,4 \\
44,4\end{array}$ & $\begin{array}{l}89 \\
85\end{array}$ & 0,0 & $\begin{array}{l}129 \\
159\end{array}$ & $\begin{array}{l}325 \\
383\end{array}$ & 136 \\
\hline $\begin{array}{l}\text { Водорастворимая } \\
\text { фракция }\end{array}$ & $\begin{array}{l}0,01 \\
0,025\end{array}$ & $\begin{array}{l}70,3 \\
67,3\end{array}$ & $\begin{array}{l}113 \\
109\end{array}$ & $\begin{array}{l}30,2 \\
35,9\end{array}$ & $\begin{array}{l}101 \\
120\end{array}$ & $\begin{array}{l}2123 \\
2416\end{array}$ & $\begin{array}{l}114 \\
130\end{array}$ & $\begin{array}{l}43,8 \\
41,4\end{array}$ & $\begin{array}{l}84 \\
79\end{array}$ & $\begin{array}{l}7,5 \\
9,4\end{array}$ & $\begin{array}{l}138 \\
174\end{array}$ & $\begin{array}{l}330 \\
387\end{array}$ & $\begin{array}{l}117 \\
137\end{array}$ \\
\hline $\begin{array}{l}\text { Водонерастворимая } \\
\text { фракция }\end{array}$ & $\begin{array}{l}0,01 \\
0,025\end{array}$ & $\begin{array}{l}68,4 \\
69,1\end{array}$ & $\begin{array}{l}110 \\
112\end{array}$ & $\begin{array}{l}36,6 \\
33,7\end{array}$ & $\begin{array}{l}122 \\
112\end{array}$ & $\begin{array}{l}2502 \\
2330\end{array}$ & $\begin{array}{l}135 \\
126\end{array}$ & $\begin{array}{l}47,9 \\
43,5\end{array}$ & $\begin{array}{l}92 \\
83\end{array}$ & $\begin{array}{l}7,3 \\
9,2\end{array}$ & $\begin{array}{l}135 \\
170\end{array}$ & $\begin{array}{l}351 \\
402\end{array}$ & $\begin{array}{l}124 \\
143\end{array}$ \\
\hline Контроль & вода & 61,7 & 100 & 29,9 & 100 & 1848 & 100 & 52,2 & 100 & 5,4 & 100 & 281 & 100 \\
\hline
\end{tabular}

Сбор урожая проводился регулярно по мере созревания плодов, при этом урожай учитывался с каждого куста отдельно.

Срєдние (из двадцати) данные по общему урожаю с куста представлены в табл. 1. Из таблицы видно, что обработка корневой системы рассады томатов и гогошар с последующим опрыскиванием растений в грунте водными растворами калиевых солей как суммарной пробы ПФК, так и отдельных ее фракций положительно сказалась на урожайности этих культур. Урожай томатов увеличился на 13,6 - 35,4 , а гогошєр - на $15,6-43,2 \%$.

Лучший эффект по урожаю гогошар дала предпосадочная обработка корней солью водонерастворимой фракции ПФК; при $0,025 \%$-ной концентрации раствора - 43,2\%. Урожай томатов был выше на $35,4 \%$ при. использовании 0,01\%-ного раствора той же фракции.

\section{2. Действие калиевой соли ПФК и отдельных фракций на урожайность фасоли овощной}

Семена фасоли замачивались в течение 24 ч в $0,1 \%$-ных растворах калиевых солей ПФК и отдельных фракций. Опыт ставился по методике, использованной И. Дагисом, И. Рыбаковым и др. [4, 5].

После замачивания семена просушивались на воздухе и высаживались в грунт. Посадка проведена 5 июля 1969 г. Всходы появились уже через неделю. Дружнее взошли семена, обработанные растворами стимуляторов.

Наблюдения проводились через две недели после появления всходов. Для измерений из каждого варианта бралось по пяти растений и измерялись: 1) высота стебля до- первых листьев; 2) количество листьев; 3) сырой вес одного растения.

Данные измерений после статистической обработки методом дисперсионного анализа [6] представлены в табл. 2.

Дальнейшие наблюдения за развитием растений показали, что фасоль опытных вариантов развивалась лучше и расцвела на четыре дня раньше контрольных растений.

Урожай собран 3 сентября. Семена 100 растений каждого варианта просушивались на воздухе и взвешивались. Величина общего урожая со. 100 растений приведена в табл. 2. 
Таблица 2

Сравнительная эффективность действия 0,1\%-ных растворов калиевых солей ПФК и отдельных фракций на развитие фасоли овощной

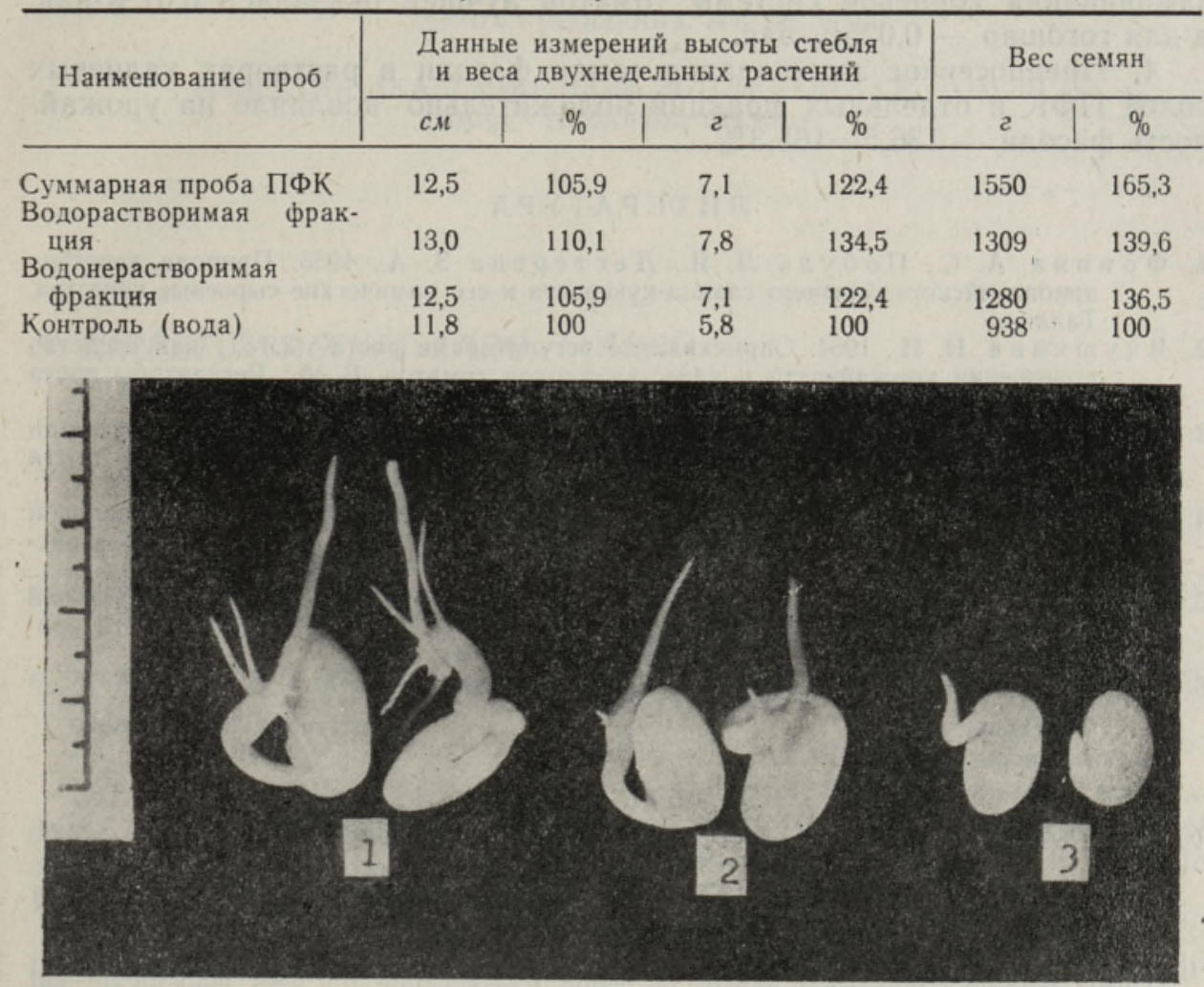

Влняние калиевых солей отдельных фракций ПФК на прорастание фасоли при 24-часовом замачивании.

1 - водорастворимая, 2 - водонерастворимая, 3 - контроль (вода).

Сравнение соответствующих величин, представленных в табл. 2, пока. зывает, что замачивание семян фасоли перед посадкой в грунт в водных растворах калиевых солей как суммарной пробы ПФК, так и отдельных ее фракций положительно влияет на развитие растений и урожайность.

Из опробованных стимуляторов лучший эффект на урожайность этой культуры был получен от замачивания семян в водном растворе соли суммарной пробы ПФК - 165,3\%.

В лабораторных условиях изучалось действие водных растворов калиевых́ солей вышеописанных фракций на прорастание семян фасоли. Наблюдения показали, что замачивание семян в течение 24 и в раствоpax $0,1 \%$-ной концентрации значительно повышает интенсивность их прорастания, при этом наиболее эффективным оказалось действие водорастворимой фракции (см. рисунок).

Результаты опытов позволяют сделать следующие выводы:

1. Замачивание корневой системы рассады томатов и гогошар в Растворах калиевых солей ПФК и отдельных фракций и опрыскивание растений в грунте соответствующими растворами стимуляторов усиливают ростовые процессы растений и повышают урожай томатов на $14-35$, гогошар на $15-43 \%$ по сравнению с контролем. 
2. Наблюдения показали, что наиболее эффективным действнем обладает калиевая соль водонерастворимой фракции.

3. Из опробованных концентраций растворов стимуляторов для замачивания корневой системы томатов лучшей оказалась $0,01 \%$-ная, а для гогошар - $0,025 \%$-ная.

4. Предпосевное замачивание семян фасоли в растворах калиевых солей ПФК и отдельных фракций положительно повлияло на урожайность фасоли - 136,5-165,3\%.

\section{ЛИТЕ РА Т У Р А}

1. Фомина А. С., Побууль Л. Я., Дегтерева 3. А., 1965., Природа керогена прибалтийского горючего сланца-кукерсита и его химические сырьевые качества. Таллин.

2. Я к ушкин а Н. И., 1964. Опрыскивание регуляторами роста (2,4-Д) как средств) повышения урожайности и качества плодов томатов. В сб.: Регуляторы роста растений. Воронеж: 146-158.

3. Чуй ков а Л. В., Рогатовска я А. А., 1964. Влияние гиббереллина на урожай и изменение физиологических процессов у томатов. В сб.: Регуляторы роста растений. Воронеж: 55-60.

4. Дагис И. К., Кристутите Я., 1963. Влияние гетероауксина и гибберелловой кислоты на рост и урожай фасоли. В сб.: Гиббереллины и их действие на растения. М.: 194-197.

5. Ры ба ко в И. М., Б ал ашов Н. Н., 1968. Влияние микроэлементов на урожай овощной фасоли и устойчивость ее к бактериозу. Тр. Молдавского ин-та орошаемого земледелия и овощеводства (2) : 40-44.

6. Доспехов Б. А., 1967. Основы методики полевого опыта. М.
Ннститут химии
Академии наук Эстонской ССР
Поступила в редакцию 18/II 1970

\section{VEERA PUNGA, A. FOMINA, Z. DEGTERJOVA, I. POPUSOI}

\section{POLUFUNKTSIONAALSETE HAPETE ERI FRAKTSIOONIDE BIOLOOGILINE MOJU JUURVILJADE JA KAUNVILJADE ARENEMISELE}

Uuriti polüfunktsionaalsete hapete ja nende fraktsioonide nii vees lahustuvate kui ka mittelahustuvate kaaliumisoolade bioloogilist mōju tomati, pipra ja türgi oa arenemisele.

Selgus, et tomati- ja pipraistikute juurte leotamine pōlevikivist saadud kasvustimulaatori $0,01-0,025 \%$-liste lahustega ja järgnev kahekordne taimede piserdamine vegetatsiooniperioodil samade ja samades. kontsentratsioonides lahustega intensiivistab taimede arenemist ning tõstab tomati ja pipra saaki.

Seemnete niisutamine 24 tunni jooksul kasvustimulaatori $0,1 \%$-lises lahuses suurendab oa saaki kuni $65 \%$.

Polüfunktsionaalsete hapete fraktsioonide uurimine näitas, et nad kõnesolevatele kultuuridele mõjuvad erinevalt.

\section{VEERA PUNGA, A. FOMINA, Z. DEGTERYOVA, I. POPUSHOI}

\section{STUDY OF THE BIOLOGICAL EFFECT OF SEPARATE FRACTIONS OF POLYFUNCTIONAL ACIDS ON VEGETABLES AND BEANS}

The biological effect of potassium salts of polyfunctional acids and their fractions (soluble and insoluble in water) on the evolution of tomatoes, pepper and haricot was studied.

As a result of the study, the moisting of roots of tomato and pepper seedlings in solutions of shale growth stimulator in concentrations from 0.01 to 0.025 per cent and the ensuing twice-repeated spraying of plants with solutions of the stimulator in above-mentioned concentration intensifies the evolution of plants and increases the tomato and pepper yields.

24-hour-moisting of haricot seeds in 0.1 per cent solution of shale growth stimulator before planting increases the yield of haricot 65 per cent.

The studied fractions of polyfunctional acids affect the evolution of plants in a different manner. 